UDC 579:631.461:57.083.13

\title{
INFLUENCE OF SUBSTANCES OF DIFFERENT CHEMICAL COMPOSITION ON VIABILITY OF DIAZOTROPHS ON SEEDS OF AGRICULTURAL CROPS
}

\author{
S. F. Kozar, T. A. Yevtushenko, V. N. Nesterenko \\ Institute of Agricultural Microbiology and Agroindustrial Manufacture of the National Academy \\ of Agrarian Sciences of Ukraine, Chernihiv, Ukraine; e-mail: ismav@ online.ua \\ The influence of carbohydrates, polyatomic alcohols, sodium chloride and compounds of protein \\ nature on the safety of diazotrophs on seeds of agricultural crops has been studied. The most promising \\ substances and their complexes to maintain the viability of nitrogen-fixing bacteria were determined. It \\ has been established that the most effective are complexes of chemical compounds, because under their \\ influence, the number of microbial cells on seeds was higher in comparison with other variants. The \\ obtained study results can be used to develop new ways to increase the viability of useful soil \\ microorganisms for their introduction into agrocenosis.
}

Key words: diazotrophs, complex of chemical substances, safety, vitality, dormant state.

The associative and symbiotic nitrogen-fixing bacteria, developing in the root zone of plants, can improve their nitrogen nutrition, as well as stimulate the growth and development of crops [1, 2]. However, as a result of the action of various factors, mainly abiotic, diazotrophs may lose their viability, which should be taken into account when using inoculants intended to increase the productivity of cultivated plants. Particularly critical this is during the period of time from the bacteritisation of the seeds before the development of the root system of the plant.

At the same time, promising solutions to the problem may be the study of the peculiarities of the transition of microorganisms to rest state, characterized by a decrease in the activity of metabolic processes, but increased viability. Well-known forms of rest (for example, bacilli spores, Azotobacter cysts), in which bacteria can be stored for a long time. Non-spore forming bacteria are able to transit to rest state without forming specific structural forms: they include certain types of microorganisms that are capable of active fixing of atmospheric nitrogen, in particular Azospirillum brasilense [3] and Bradyrhizobium japonicum [4].

One of the ways to extend the storage time of bacterial inoculants may be the addition of chemical additives to the medium. However, the influence of chemicals (polymers, polyhydric alcohols, carbohydrates, substances of protein nature, etc.) on microorganisms depends on the duration of their action. The variety of nature and the chemical structure of compounds, which can positively affect the viability of bacteria, also determines the various mechanisms of their action. 
In connection with the above, the study of the impact of substances of different nature on microorganisms is relevant.

Materials and methods. The study was carried out with Bradyrhizobium japonicum M-8 [5], Azospirillum brasilense 410 [6] in the treatment of Lehenda variety soybean seeds. At the same time, bacteria were cultivated both separately and in a mixed culture. The consortium of Azotobacter vinelandii and Azotobacter chroococcum M-70/2 [7] was used to treat seeds of marrow squash of Hrybovskyi variety, Rhizobium radiobacter 204 [8], for treatment of winter wheat of Poliska 90 variety, Rhizobium leguminosarum 31 for treatment of Tsarevych variety peas.

Microorganisms were obtained from the collection of useful soil microorganisms at the Institute of Agricultural Microbiology and Agroindustrial Manufacture of the NAAS. We express our sincere gratitude to the authors for kindly provided strains.

Applied substances of different chemical nature: carbohydrates (sodium alginates, starch, agaragar, glucose, and also molasses, which in addition to carbohydrates contains a complex of chemical compounds); polyatomic alcohol (mannitol); substances of protein nature (gelatine); sodium chloride and chemical substances complexes (CSC 1 on the basis of polymers and protein compounds, CSC 2 on the basis of polyhydric alcohols and carbohydrates, CSC 3 on the basis of polyhydric alcohols, carbohydrates, and protein substance).

Studied microorganisms were grown under periodic cultivation on a microbiological rocker $\left(220 \mathrm{rpm} / \mathrm{min}\right.$ at $\left.28^{\circ} \mathrm{C}\right)$.

B. japonicum was cultivated in a liquid digestive medium of the following composition $\left(\mathrm{g} / \mathrm{dm}^{3}\right)$ : a decoction of pea seeds - 100, glucose - 10, sucrose - 5, $\left(\mathrm{NH}_{4}\right)_{2} \mathrm{SO}_{4}-1.0, \mathrm{KH}_{2} \mathrm{PO}_{4}-0.5, \mathrm{~K}_{2} \mathrm{HPO}_{4} 3 \mathrm{H}_{2} \mathrm{O}$ $-0.5, \mathrm{MgSO}_{4} \cdot 7 \mathrm{H}_{2} \mathrm{O}-0.2, \mathrm{CaCO}_{3}-0.3$.

For $A$. brasilense culture, the digestive medium of the following composition $\left(\mathrm{g} / \mathrm{dm}^{3}\right)$ was used: corn extract - 30.0, molasses - 30.0, $\left(\mathrm{NH}_{4}\right)_{2} \mathrm{SO}_{4}-0.10, \mathrm{KH}_{2} \mathrm{PO}_{4}-0.25, \mathrm{~K}_{2} \mathrm{HPO}_{4} \cdot 3 \mathrm{H}_{2} \mathrm{O}-0.25$, $\mathrm{MgSO}_{4} \cdot 7 \mathrm{H}_{2} \mathrm{O}-0.20, \mathrm{CaCO}_{3}-0.30$.

For mixed cultivation of $A$. brasilense and B. japonicum, the digestive medium of the following composition $\left(\mathrm{g} / \mathrm{dm}^{3}\right)$ was used: fodder yeasts (dry) - 3.0, molasses - 5.0, $\left(\mathrm{NH}_{4}\right)_{2} \mathrm{SO}_{4}-1.0, \mathrm{KH}_{2} \mathrm{PO}_{4}-$ $0.15, \mathrm{~K}_{2} \mathrm{HPO}_{4} \cdot 3 \mathrm{H}_{2} \mathrm{O}-0.25, \mathrm{MgSO}_{4} \cdot 7 \mathrm{H}_{2} \mathrm{O}-0.10, \mathrm{CaCO}_{3}-0.50$.

$R$. radiobacter was cultivated in the digestive medium of the following composition $\left(\mathrm{g} / \mathrm{dm}^{3}\right)$ : pea decoction - 100.0; sugar - 40.0; $\left(\mathrm{NH}_{4}\right)_{2} \mathrm{SO}_{4}-1.0 ; \mathrm{KH}_{2} \mathrm{PO}_{4} \cdot 2 \mathrm{H}_{2} \mathrm{O}-0.5 ; \mathrm{K}_{2} \mathrm{HPO}_{4}-0.5 ; \mathrm{MgSO}_{4} \cdot 7 \mathrm{H}_{2} \mathrm{O}-$ $0.3 ; \mathrm{CaCO}_{3}-1.0$; tap water up to $1.0 \mathrm{dm}^{3} ; \mathrm{pH}$ 6.8-7.0.

Bacteria of the genus Azotobacter were cultured in a liquid nutrient medium of the following composition $\left(\mathrm{g} / \mathrm{dm}^{3}\right)$ : sucrose $-20.0 ; \mathrm{K}_{2} \mathrm{HPO}_{4} \cdot 3 \mathrm{H}_{2} \mathrm{O}-0.2 ; \mathrm{KH}_{2} \mathrm{PO}_{4}-0.2 ; \mathrm{MgSO}_{4} \cdot 7 \mathrm{H}_{2} \mathrm{O}-0.2 ; \mathrm{NaCl}-$ $0.2 ; \mathrm{K}_{2} \mathrm{SO}_{4}-0.1 ; \mathrm{CaCO}_{3}-5.0(\mathrm{pH} 7.2-7.3)$. 
Seeds of agricultural crops were bacterized simultaneously with the use of chemicals. The initial bacterial count was $2 * 10^{5}$ cells per seed. Bacterized seeds were stored without the access of light at $22 \pm$ $2{ }^{\circ} \mathrm{C}$.

The number of bacteria on the seeds was determined at days $7,14,21,30,60$, and 90 by generally accepted microbiological methods $[9,10]$.

The obtained digital material was processed by the method of variation statistics using Excel and Statistica software, the probability of the difference was determined by Student t-test.

Results and discussion. Transition of diazotrophs to rest state and preserving under the effects of chemical compounds can be achieved by the use of chemicals that create stress conditions for microorganisms, but do not lead to the death of a bacterial cell (for example, polyhydric alcohols), as well as due to the protective effect of chemicals through the ability to form protective coating on the cell surface (for example, polymers and protein substances).

In the course of the study, it was found that the bacteria remained on seeds compared with the control variant under the action of different chemicals. Fig. 1 provides the results of study the viability maintaining of soybean rhizobia under the action of studied compounds.

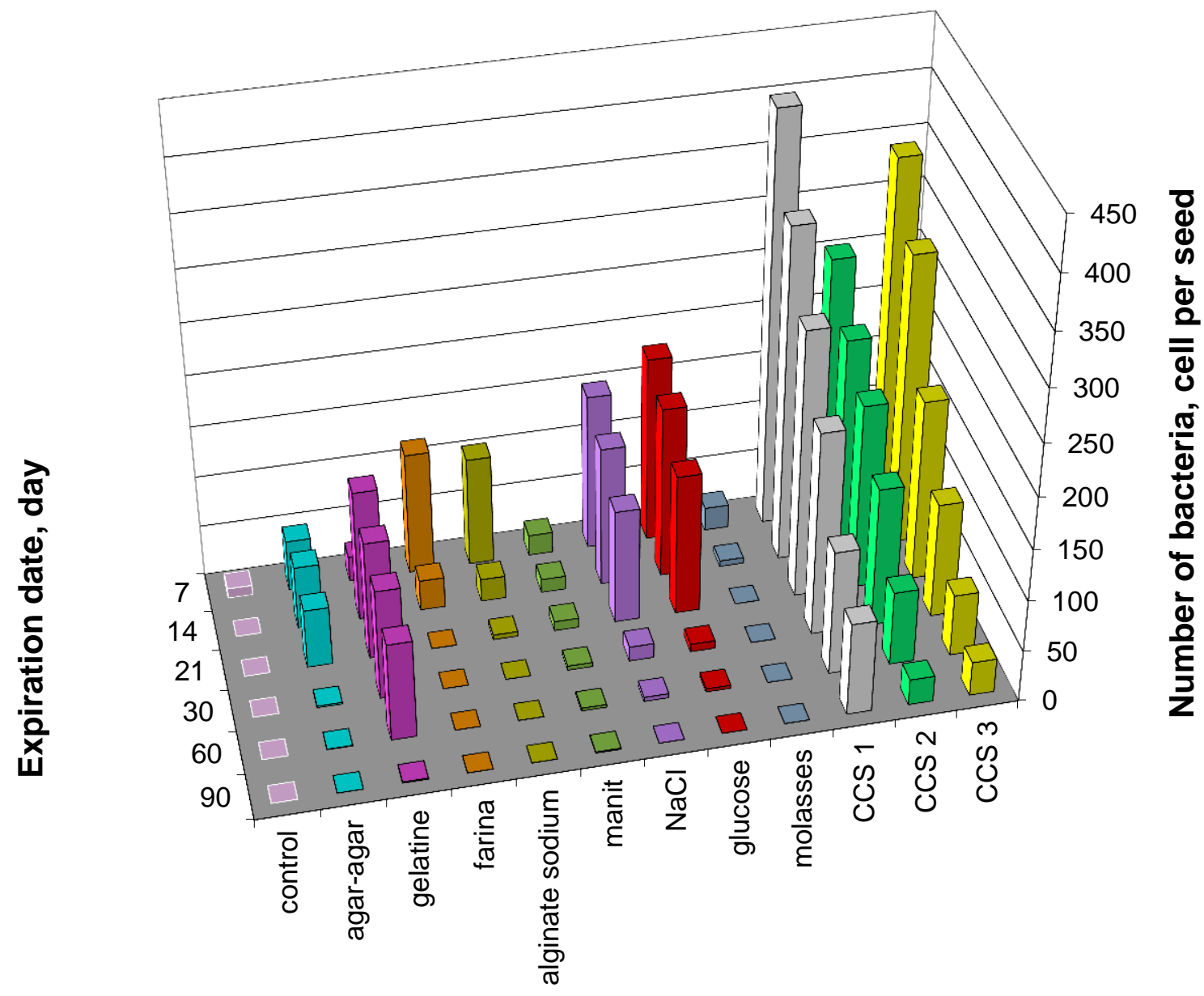

Fig. 1. Influence of chemical substances on safety of B. japonicum M-8 on soybean seeds. 
Glucose, starch, sodium alginate, and sodium chloride were found to be more effective in comparison with other substances. However, the indicators of the number of viable cells of bacteria in variants with them over time decreased, and at the end of the shelf life were at the control level.

On the basis of the obtained data, complexes of chemical substances were selected. Thus, the first complex included substances that are characterized by the protective action of bacterial cells. The second complex included substances that possess bacteriostatic action. The third complex has been developed on the basis of the components of the first two complexes.

As a result of the carried out studies, it was established that during storage of seeds for a long time the number of bacteria significantly decreased, but in variants with treatment using chemical substances complexes, rhizobia retained their viability on the seeds after treatment for the longest time. Attention should be paid to CSC 1, under the effect of which the number of soybean rhizobia was 3.5 times higher than that of CSC 2, and compared with CSC $3-2.5$ times, but did not exceed $10^{2}$ cells per seed.

In experiments with $A$. brasilense 410, it was found that all studied substances contributed to the prolongation of the maintenance term of bacteria (Fig. 2).

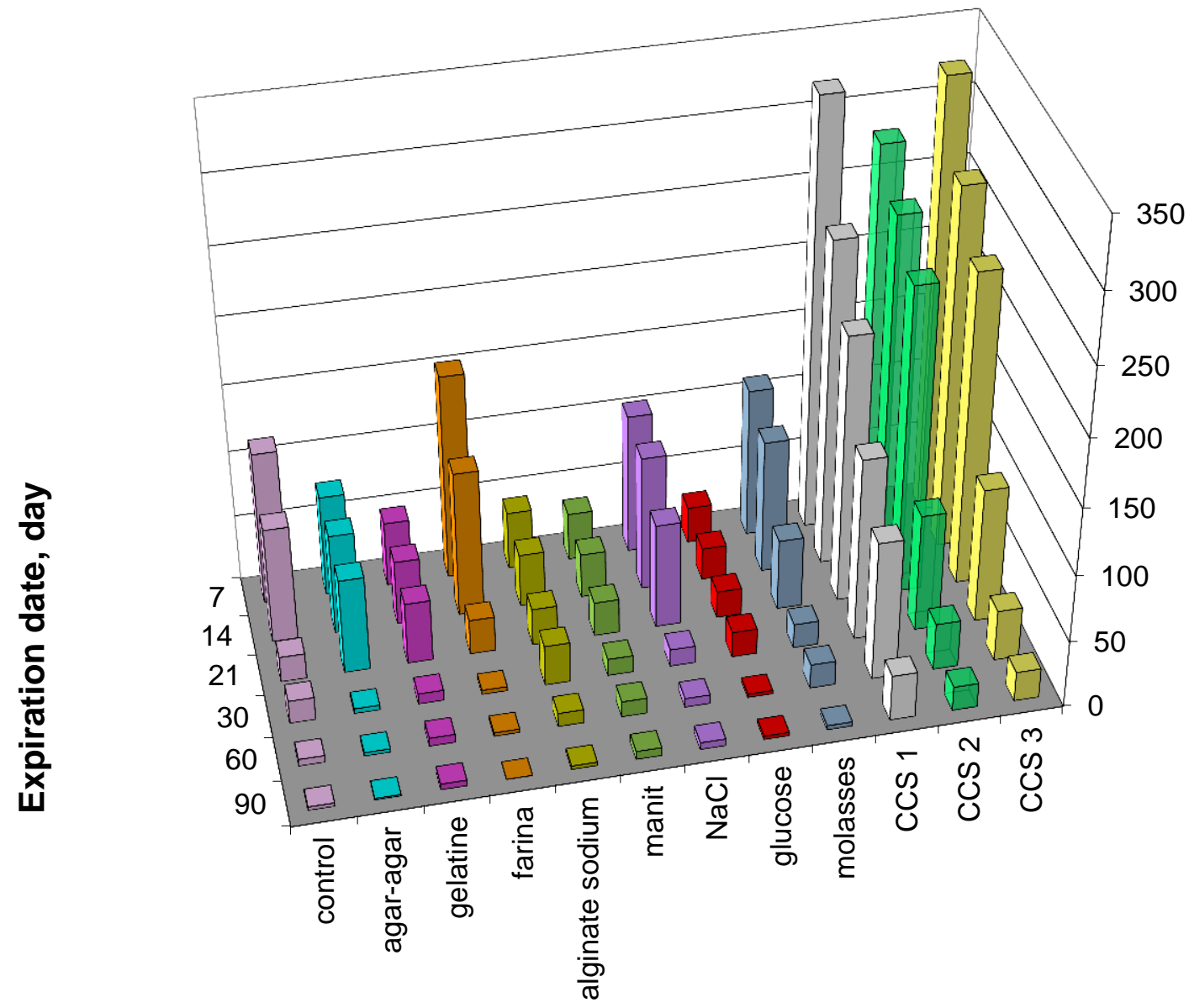

Fig. 2. Influence of chemical substances on safety of A. brasilense 410 on soybean seeds. 
However, during the whole period of storage, the highest number of microorganisms was under the use of chemical substances complexes. For example, under the effects of CSC 1, the number of azospirilla exceeded control by 13 times, in the version with CSC $2-7$ times, with CSC $3-9$ times.

From the data provided, it is seen that the number of viable cells was higher (both rhizobia and azospirilla) when using polymers, which can be explained by their protective effect.

In studying the maintenance of $B$. japonicum M-8 seeds, previously cultivated along with azospirilla, the highest positive effect on the viability of starch bacteria was found (Fig. 3), at the same time, under the effect of molasses the number of rhizobia was significantly lower compared with the other compounds throughout the storage period. After three months of storage, CSC 1 and CSC 2 were the most effective among the complexes.

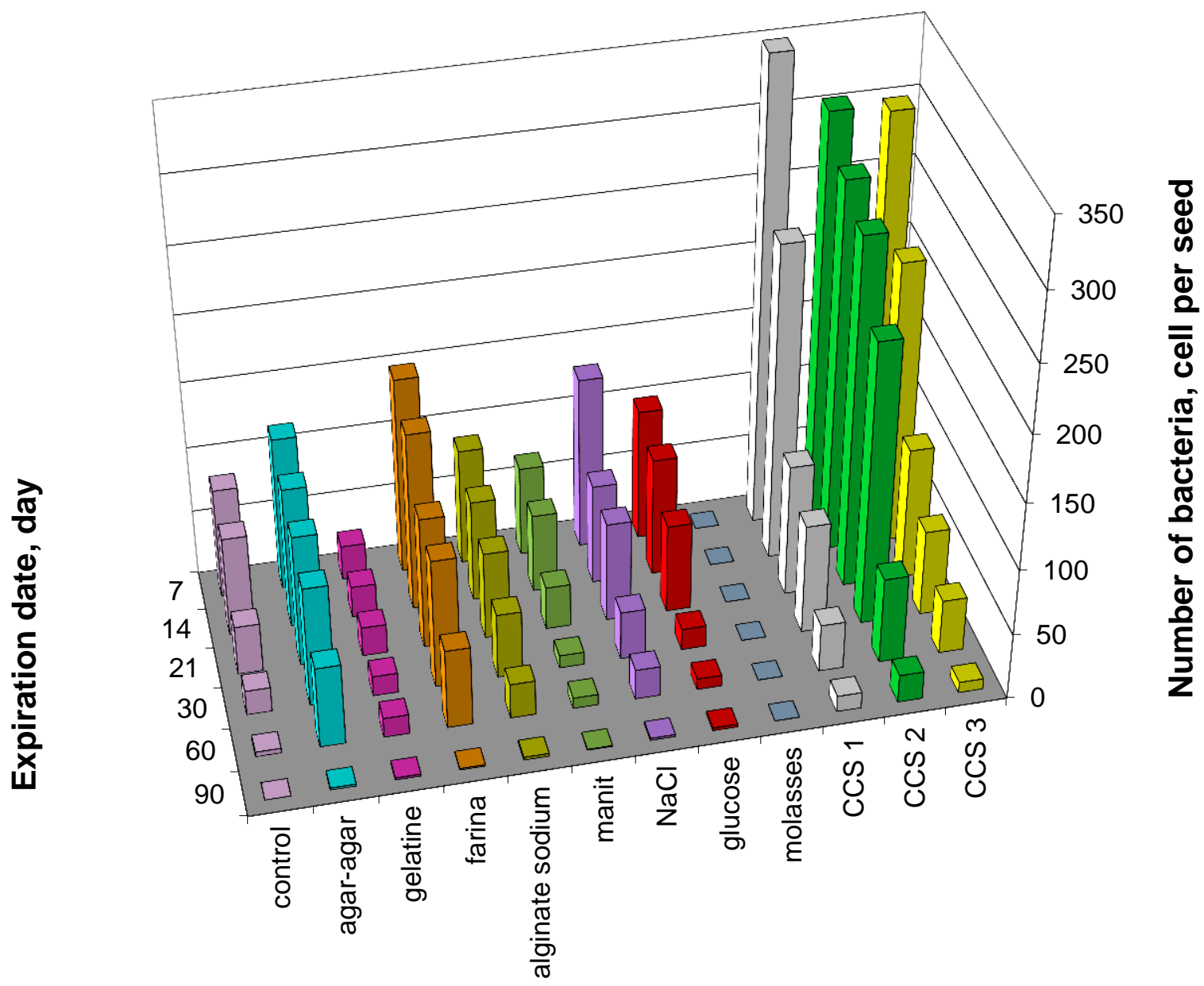

Fig. 3. Influence of chemical substances on safety of B.japonicum M-8 (in a mixed culture with A. brasilense 410) on soybean seeds.

It was established that all studied substances contributed to the extension of the maintenance period of bacteria of the genus Azotobacter on marrow squash seeds (Fig. 4). It should be noted that throughout the storage period, the number of Azotobacter was higher under the action of protective 
substances. With the use of chemical substances complexes, bacterial cells were stored on the seeds longer and their number exceeded control by 3.6 times following treatment with CSC 1, twice with CSC 2 and 2.5 times with CSC 3. At the same time, in the variant with CSC 1 the number of viable cells was $35 \%$ higher than with CSC 3.

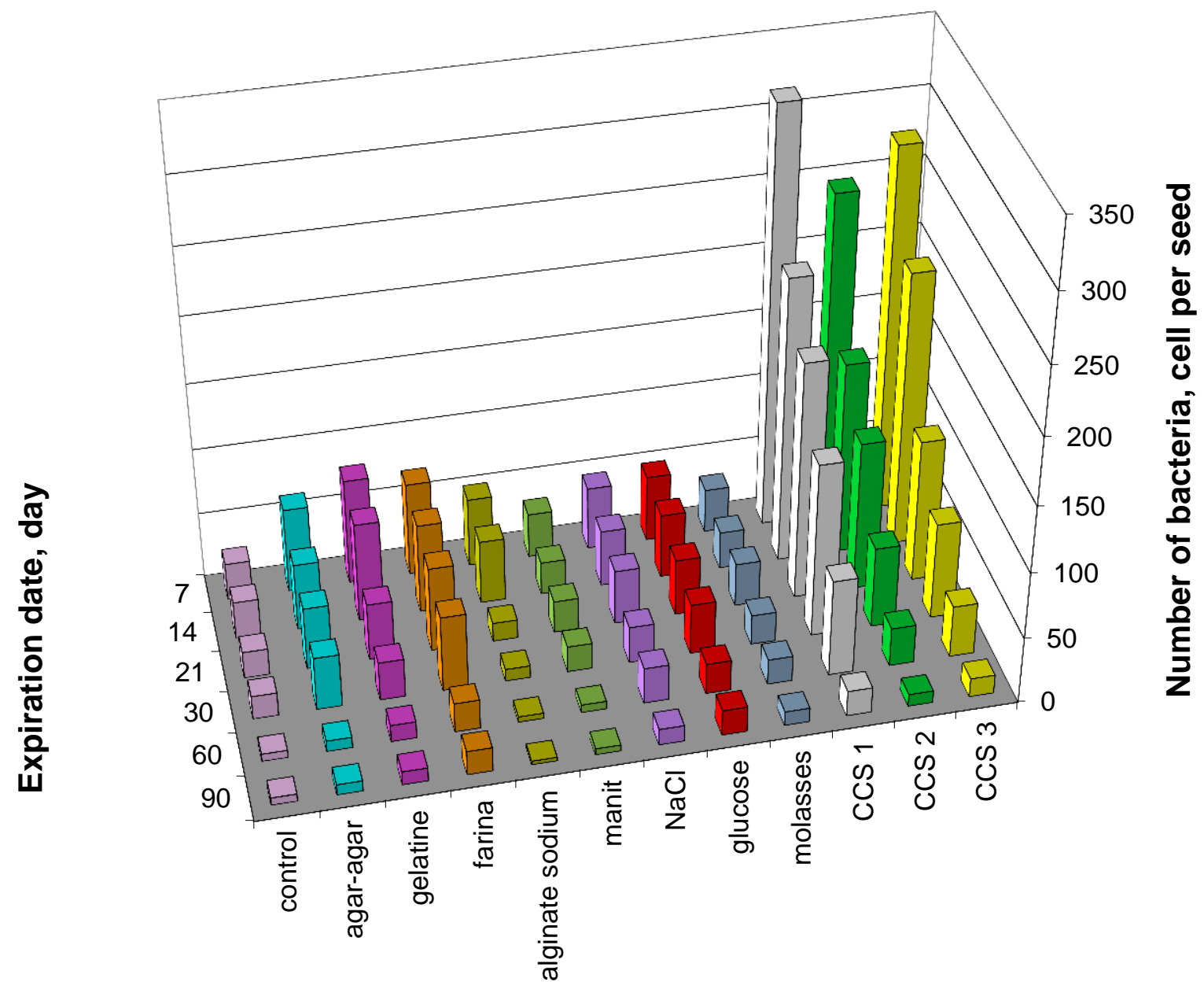

Fig. 4. Influence of chemical substances on safety of A. vinelandii and A. chroococcum M-70/2 (the total number of bacteria) on zucchini seeds.

During storage of $R$. leguminosarum 31 on pea seeds for three months, as well as in experiments with rhizobia and Azotobacter, rhizobia remained better compared to the control variant under the action of complex, which includes polymers, which can also be explained by their protective effect.

When using carbohydrates, pea rhizobia were better stored than in control, but the number of viable cells was smaller compared to variants in which the complex CSC 1 was used (Fig. 5): under its action, the number of bacteria after three months of storage exceeded control 6 times. 


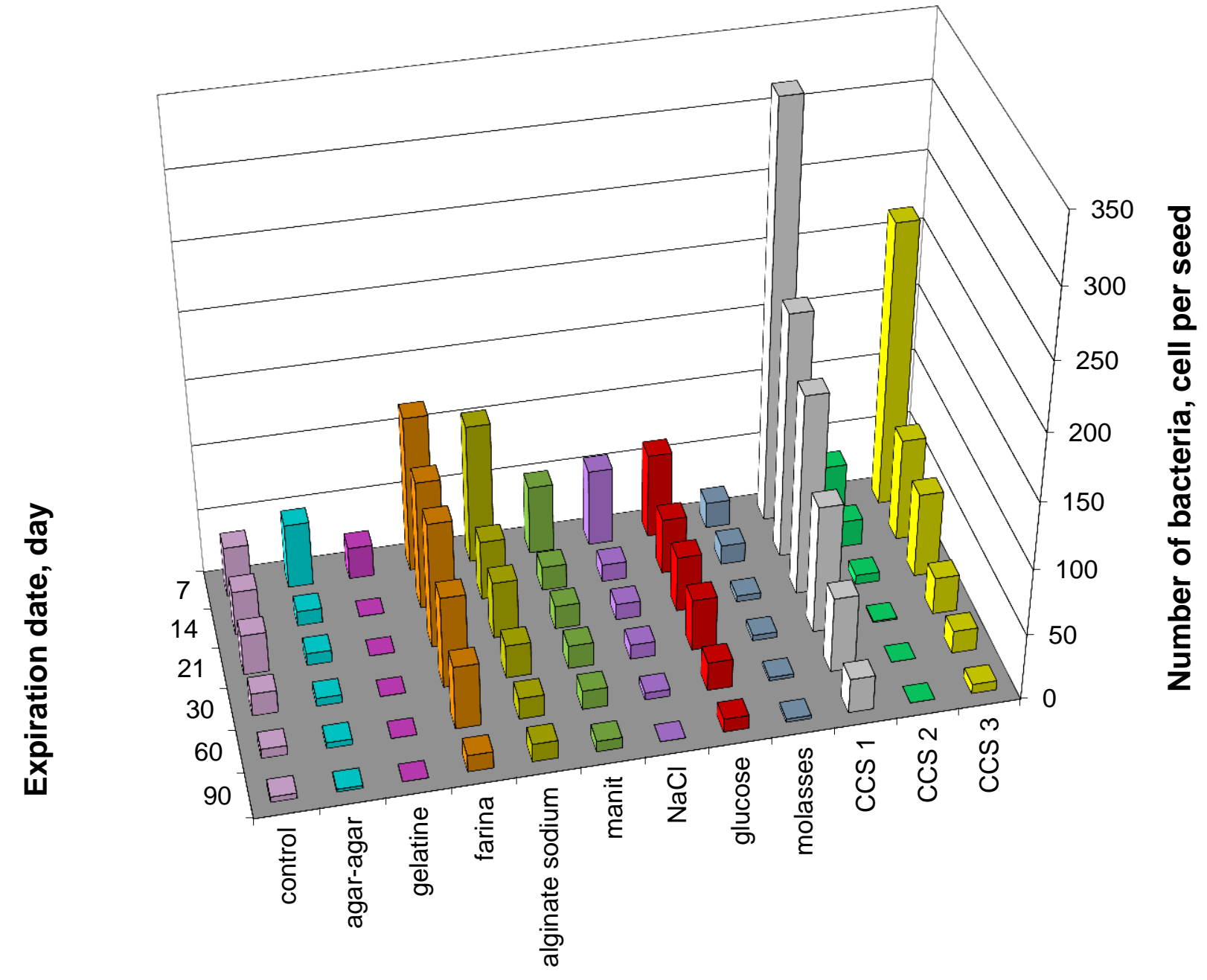

Fig. 5. Influence of chemical substances on safety of R. leguminosarum 31 on pea seeds.

Upon the storage of $R$. radiobacter 204 within three months, gelatine was effective (Fig. 6). Under the action of glucose, the number of bacteria on seeds in 7 days was the highest compared with other individual chemical compounds, but after 90 days the number of microorganisms was at level of control. All chemical substances complexes were effective during the first month, but at the end of storage, CSC 1 was the most effective, since the number of diazotrophs studied exceeded the control variant by 7 times under its action. 


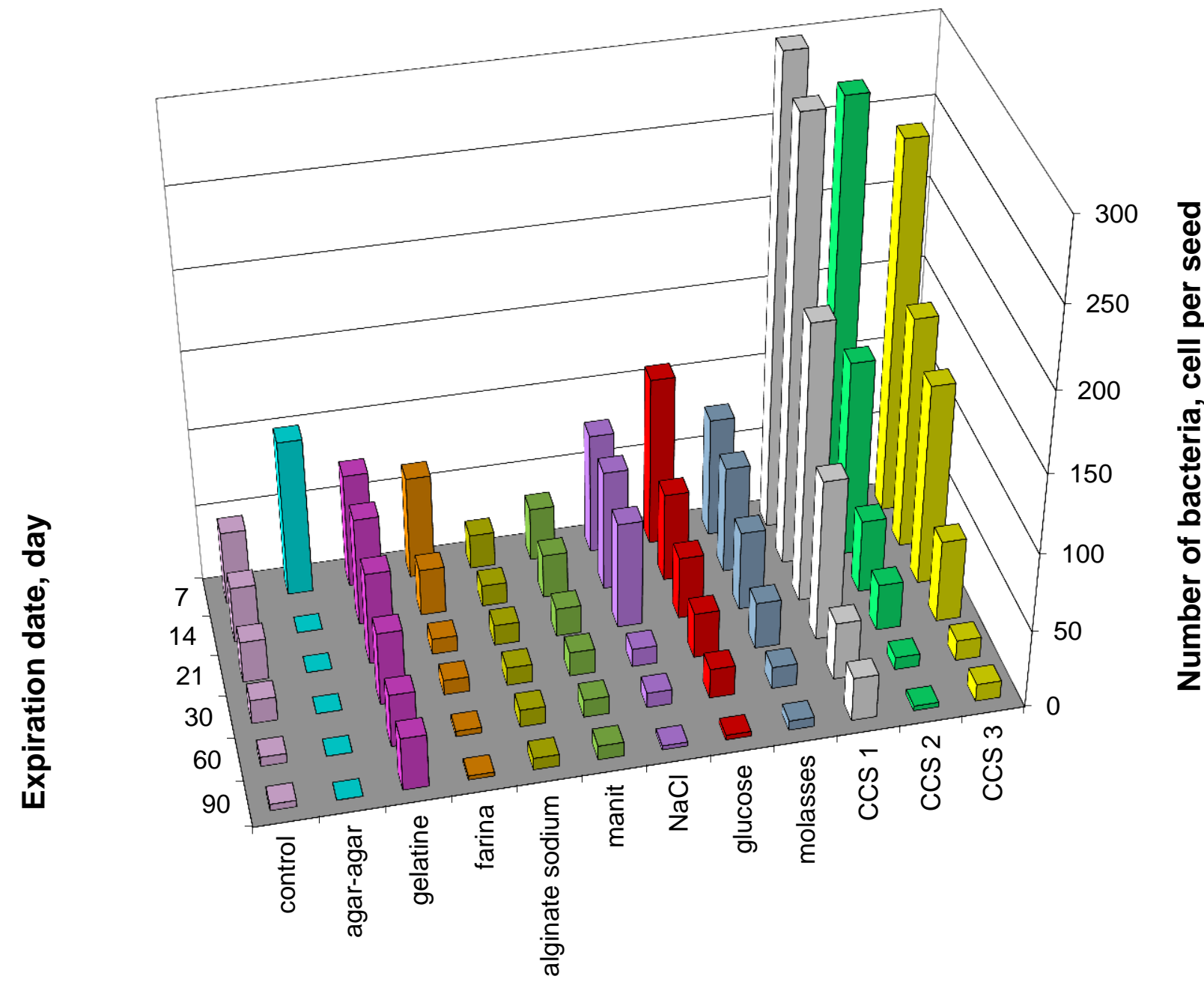

Fig. 6. Influence of chemical substances on safety of bacteria $R$. radiobacter 204 on winter wheat seeds.

Therefore, it should be noted that after seed bacterization by nitrogen fixing microorganisms under storage within three months, there is a significant decrease in the number of viable cells of bacteria. The addition of substances of different chemical nature does not completely stop this process, but it reduces its intensity. To preserve diazotrophs in the rest state on the seeds, it is expedient to use chemical substances complexes, since their effectiveness is much higher than the use of certain substances. The obtained study results can be used in further development of methods for improving the viability of useful soil microorganisms for their introduction into agrocenosis. 
1. Біологічний азот / [Патика В. П., Коць С. Я., Волкогон В. В. та ін]; ред. В. П. Патики. К. : Світ, 2003. - 422 с.

2. Мікробні препарати у землеробстві. Теорія і практика : [монографія] / [Волкогон В. В., Надкернична О. В., Ковалевська Т. М. та ін.]; за ред. В. В. Волкогона. - К.: Аграрна наука, 2006. $-311 \mathrm{c}$.

3. Разнообразие морфотипов покоящихся клеток и условия их образования у Azospirillum brasilense / [Мулюкин А. Л., Сузина Н. Е., Погорелова А. Ю. и др.] // Микробиология. — 2009. T. 78, № 1. - C. 42-51.

4. Hirsch A. M. How rhizobia survive in the absence of a legume host, a stressful world indeed / A. M. Hirsch // Symbioses and stress: joint ventures in biology. - Springer, Netherlands, Dordrecht, 2010. - P. 377-391.

5.Пат. 39545 Україна, МПК С 12 N 1/20, С 05 F 11/08. Штам бульбочкових бактерій Bradyrhizobium japonicum M-8, який використовують для приготування бактеріального препарату, що підвищує урожайність сої / М. 3. Толкачов, В. П. Патика, І. О. Каменєва, Л. Ю. Грітчіна ; заявл. 06.10.2000 ; опубл. 15.06.2001, Бюл. № 5.

6.Пат. 1806123 СССР, МКИ С 05 F 11/08 C12 N1/20. Штамм бактерий Azospirillum lipoferum для производства удобрений под райграс пастбищный и костец безостый / Волкогон В. В., Мальцева Н. Н., Онищенко Л. И. и др. - № 4916559/13 ; заявл. 05.03.91 ; опубл. 30.03.93., Бюл. № 12 .

7.А. c. 1476831 ССCР, МКИ ${ }^{4}$ C 05 F11/08. Консорциум штаммов бактерий Azotobacter chroococcum и Azotobacter vinelandii для производства бактериальных удобрений под кормовую свеклу и капусту / Ю. М. Мочалов, В. И. Канивец. — № 4086625 / 30-13 ; заявл. 02.07 .86 ; опубл. 03.01.1989.

8.A.C. СССР №1621433 A1C05F11/08, C12№1/20 Штамм бактерий Agrobacterium radiobacter для производства бактериального удобрения под рис и пшеницу / Н.К. Шерстобоев, А.В. Хотянович, В.Ф Патыка. - Заявл. 28.09 .88

9.Теппер Е. 3. Практикум по микробиологии : [учебное пособие для вузов] / Теппер Е. 3., Шильникова В. К., Переверзєва Г. И.; [ред. Шильниковой В. К.] ; 6-е изд. перераб. и доп. — М.: Дрофа, 2005. - 256 с.

10. Сэги Й. Методы почвенной микробиологии / Й. Сэги [пер. с венг. И. Ф. Куренного; ред. Г. С. Муромцева]. - М. : Колос, 1983. - 296 с. 
ВЛИЯНИЕ ВЕЩЕСТВ РАЗНОГО

ХИМИЧЕСКОГО СОСТАВА НА

ЖИЗНЕСПОСОБНОСТЬ ДИАЗОТРОФОВ

HA CEMEHAX

СЕЛЬСКОХОЗЯЙСТВЕННЫХ КУЛЬТУР

Козар С.Ф., Евтушенко Т. А.,

Нестеренко В. Н.

Институт сельскохозяйственной

микробиологии и агропромышленного

производства НААН, г. Чернигов

Изучено влияние углеводов, многоатомных спиртов, натрия хлорида и соединений белковой природы на сохранность диазотрофов на семенах сельскохозяйственных культур. Определень наиболее перспективные вещества и их комплексы для поддержания жизнеспособности азотфиксирующих бактерий. Установлено, что наиболее эффективными являются комплексы химических соединений, поскольку при их влиянии численность микробных клеток на семенах была выще по сравнению с другими вариантами. Полученные результаты исследований могут быть использованы при разработки новых способов повышения жизнеспособности полезных почвенных микроорганизмов для их интродукиии в агроченозы.

Ключевые слова: диазотрофы, комплекс химических веществ, сохранность, жизнеспособность, состояние покоя.
ВПЛИВ РЕЧОВИН РІЗНОГО

ХІМІЧНОГО СКЛАДУ НА

ЖИТТЕЗДАТНІСТЬ ДІАЗОТРОФІВ НА

НАСІННІ СІЛЬСЬКОГОСПОДАРСЬКИХ

кУЛЬТУР

Козар С.Ф., Свтушенко Т. А.,

Нестеренко В. М.

Інститут сільськогосподарської мікробіології та агропромислового виробництва НААН,

м. Чернігів

Вивчено вплив вуглеводів, багатоатомних спиртів, сполук білкової природи $і$ натрію хлориду на збереженість діазотрофів на насінні сільськогосподарських культур. Визначено найбільш перспективні речовини та їх комплекси для підтримання життєздатності азотфіксувальних бактерій. Встановлено, щзо найбільш ефективними $\epsilon$ комплекси хімічних сполук, оскільки за їхньої дії чисельність мікробних клітин на насінні була вищзою у порівнянні $з$ іншими варіантами. Отримані результати досліджень можуть бути використані для розробки нових способів підвищення життєздатності корисних трунтових мікроорганізмів за їх інтродукиії в агроченози.

Ключові слова: діазотрофи, комплекс хімічних речовин, збереженість, життездатність, стан спокою. 